\section{Successful Removal of Thrombus from Renal Vein after Renal Transplantation}

British Medical fournal, 1970, 1, 154-156

Complications following renal homotransplantation are frequent and it is often difficult to distinguish surgical complications from rejection of the transplanted kidney. The following case, in which the venous return from the graft was occluded by a thrombus ascending from a venous thrombosis of leg and in which kidney function returned after removal of the clot, shows the importance of early diagnosis and treatment of surgical problems.

\section{CASE Report}

A 53-year-old man developed renal failure owing to polycystic disease early in 1968 and was maintained by twice-weekly haemodialysis. In preparation for renal transplantation bilateral nephrectomy was performed in two stages in September and October 1968. The spleen was not removed. The patient had suffered from varicose veins for many years. He had bilateral long saphenous incompetence with gross varicosities above and below the knee on both sides.

On 8 January 1969 a cadaver kidney was transplanted into his right iliac fossa. The artery was anastomosed end-to-end to the hypogastric artery and the vein was joined end-to-side to the external iliac vein. The donor ureter was implanted into the bladder, using a submucosal tunnel. The warm ischaemia time was 135 minutes and the total ischaemia time 240 minutes. There was no significant output of urine until the 10th day, when he passed $298 \mathrm{ml}$., and he was supported by frequent haemodialyses over this period. After this the urinary output rapidly increased, reaching 3 litres by the 14th day. Standard immunosuppressive treatment with azathioprine and steroid was given. On the seventh day he complained of slight pain in the right calf, but only very minimal tenderness was found, and this disappeared over the next day or so. Tissue typing was carried out by Professor J. R. Batchelor, and only one definite incompatibility was identified.

On the evening of the 18 th day the patient developed sudden severe pain across the lower abdomen as he rose from sitting in a chair, the pain subsequently passing down the inside of his right thigh to his knee. At this time there was no obvious swelling of the graft but swelling occurred below the inguinal ligament. $\mathrm{He}$ passed only $78 \mathrm{ml}$. of urine overnight, whereas during the same period the previous night he had passed $1,250 \mathrm{ml}$. By the next morning a tortuous vein in the right upper thigh was definitely hard. The kidney seemed to be swollen in its transverse axis but was not tender. The femoral pulses were present, and there was no tenderness rectally. It was thought that the rapid onset of pain in the graft, followed by a dramatic fall in urinary output overnight, and the presence of thrombosed veins in the thigh, almost certainly indicated venous thrombosis of the graft and that rejection could be excluded. Accordingly $15 \frac{1}{2}$ hours after the onset of symptoms an exploratory operation was carried out.

The kidney was found to be tense and swollen but well vascularized. A renal biopsy was taken, and the appearances of glomeruli and tubules were later reported as being within normal limits. The iliac vein was exposed above and below the renal vein anastomosis. Above the kidney the vein was empty; below, it was packed with blood clot which extended to the limit of exposure at the inguinal ligament. The right common iliac vein was clamped just below the vena cava and the external iliac vein was opened above the inguinal ligament. A Fogarty No. 4 embolectomy catheter was passed up to the clamp, the balloon was inflated, and a large thrombus was removed on withdrawal of the catheter. The end of the thrombus appeared to be bifid, sugg zsting that one portion was lodged in the renal vein and one in the iliac vein. A brisk flow of blood and rapid reduction in size of the kidney followed the removal of this clot, but on two further occasions over the next 30 minutes further thrombus formed and was removed in the same way. Attempts to clear the femoral vein of thrombus were unsuccessful and the external iliac vein was ligated below the renal vein to prevent further thrombosis. After operation the patient was anticoagulated with heparin, but this had to be counteracted after a few hours because of profuse bleeding from the wound. Anticoagulation with warfarin was begun on the fifth postoperative day and was continued for 16 days.

Following relief of the renal vein thrombosis he passed over 1 litre of urine in the next 24 hours and kidney function rapidly improved. Some swelling of the right leg persisted but was not causing disability. Three weeks later he developed a deep wound infection due to a Staphylococcus aureus which was successfully treated by ampicillin and drainage of pus. He was finally discharged from hospital eight weeks after transplantation, very well and with satisfactory kidney function. A further wound abscess developed five months later, again due to Staph. aureus, which was treated by drainage without antibiotic therapy. At the time of writing he was well, with a serum creatinine of $1.3 \mathrm{mg} . / 100 \mathrm{ml}$. and a creatinine clearance of $73 \mathrm{ml} . / \mathrm{min}$., the urinary excretion of protein being $200 \mathrm{mg} . / 24$ hours.

\section{Comment}

Thrombosis of the deep veins of the leg is a relatively common complication of any type of surgery, or even bed rest, and could be expected to be even more common in renal transplantation, especially in centres where splenectomy is carried out as part of the procedure. Indeed Starzl (1964) reported that 9 out of 42 patients developed thrombophlebitis, and five probably had pulmonary emboli. The conditions which predispose to this high incidence of leg vein thrombosis, and also the lengthy manipulation of veins within the pelvis, could also be expected to predispose to thrombosis of the transplanted renal vein, yet there are surprisingly few references to thrombosis of the renal vein as a complication of transplantation.

Starzl (1964) mentioned one patient who survived removal of pulmonary embolus and plication of the vena cava for two months, during which the kidney functioned, but at necropsy the renal vein was occluded by thrombus which extended to its smallest branches. Smellie, Vinik, Freed, and Hume (1968) attempted to visualize the renal vein by pertrochanteric venography in three transplant recipients. In all three patients the renal vein was thought to be patent though only its terminal portion was demonstrated. Walsh (1969) described arterial complications but did not mention thrombosis of the renal vein. Khastagir, Montandon, Nakamoto, and Kolff (1969), in their analysis of the causes of failure in 123 renal transplants, mention two cases in which thrombosis of the renal vessels occurred as part of the rejection process, though they do not specifically describe the renal veins. Owen (1969) suggested that if diagnosed early enough it was worthwhile to explore thrombosed anastomoses, but that it was not often possible to obtain a viable kidney. We have not been able to discover any reports of this.

In our patient good renal function was still present nine months after the thrombosis of the renal vein, secondary to 
thrombosis of leg veins, was relieved at operation. We suggest that when there is a sudden fall in urinary output in a transplanted kidney with established function, thrombosis of the renal vein may have occurred and an early exploration may enable this to be successfully relieved.

We wish to thank Professor J. R. Batchelor for carrying out the tissue typing.
S. D. ClaARKe, M.CH., F.R.C.S,
J. A. KENNEDY, M.CH., F.R.C.S.
J. C. HEWITT, M.D., F.F.A. R.C.S.
J. McEvoY, M.D., M.R.C.P.
M. G. MCGEOWN, M.D., PH.D., F.R.C.P.ED.
S. D. Nelson, M.R.C.P.I.

Renal Unit, Belfast City Hospital, Belfast.

\section{REFERENCES}

Khastagir, B., Montandon, A., Nakamoto, S., and Kolff, W. J. (1969). Archives of Internal Medicine, 123, 8.

Owen, K. (1969). British fournal of Hospital Medicine, 2, 1216.

Smellie, W. A. B., Vinik, M., Freed, T. A., and Hume, D. M. (1968). Surgery Gynecology and Obstetrics, 126, 777

Starzl, T. E. (1964). Experience in Renal Transplantation. Philadelphia, Saunders.

Walsh, A. (1969). Transplantation Proceedings, 1, 178.

\section{Studies on March Haemoglobinuria}

British Medical fournal, 1970, 1, 155-156

March haemoglobinuria is a transient disorder which occurs predominantly in healthy young men after walking or running. There is only one reported case of its occurrence in a woman. The average duration is from a few months to two years. Davidson (1964) showed that the haemolysis was due to trauma to circulating erythrocytes in the soles of the feet. No underlying defect has been proved to exist.

\section{CASE Report}

A healthy 24-year-old soldier presented with dark red urine after an 8 -mile $(13-\mathrm{km}$.) road run in thin-soled shoes. This eveni was recognised as march haemoglobinuria. The condition persisted for 12 months and he remained in positive good health Haemoglobinuria was preceded by excessive aching in the calves during the run. The onset, about 20 minutes after a 6-mile $(10-\mathrm{km}$.) run, was heralded by a sudden aching in the loins. Running in thick-soled shoes or on grass does not result in haemoglobinuria.

The nature of the disorder was explained to the patient when he first presented. He volunteered to be the subject of further investigations.

\section{METHODS}

Blood was withdrawn without stasis from large antecubital veins and was gently transferred to heparinized bottles and mixed. After brief centrifugation the plasma was aspirated and either treated immediately or stored at $-20^{\circ} \mathrm{C}$. Serum complement, red-cell fragility, and autohaemolysis were estimated according to Dacie and Lewis (1963). Plasma haemoglobin was estimated by the method of Vanzetti and Valente (1965). The normal range for the conditions pertaining to the present study is $3-10 \mathrm{mg} . / 100 \mathrm{ml}$. Plasma haptoglobin was estimated by the electrophoretic method of Louderback and Shanbrom (1968). The normal range for the laboratory is $30-150 \mathrm{mg} . / 100 \mathrm{ml}$. Urine was examined for cystine by the qualitative cyanide-nitroprusside test according to Varley (1967).

\section{Preliminary Investigations}

The haemoglobin was $13.6 \mathrm{~g} . / 100 \mathrm{ml}$. The red blood cell indices, white blood cell count, reticulocyte count, erythrocyte sedimentation rate, plasma protein electrophoresis, and serum bilirubin were normal. Wassermann reaction, Ham's test, Donath-Landsteiner test, and direct Coombs test were negative. Cold agglutinins were not detected. Osmotic fragility of red cells was normal. Fetal cells were not seen in 100 high-power fields, and Singer's test for fetal haemoglobin was negative. No abnormal haemoglobin was found. The red blood cell glucose-6-phosphate dehydrogenase, the serum creatine phosphokinase immediately after a run, and a chest $x$-ray examination were normal. Urine examination showed nothing abnormal except for a period of about six hours after a run.

\section{InVESTigations on HaEMOlytic Mechanism}

The patient and three controls of similar weight made the same run of 6.4 miles $(10.3 \mathrm{~km}$.) on a roadway in about 36 minutes. All wore the same pattern of thin-soled shoes. The patient made the test-run six times with a minimum interval of seven days. In run 1 he wore thin-soled shoes. The serum haemoglobin rose 74 mg. and there was heavy haemoglobinuria. In run 2 he wore thick rubber-soled running shoes. The serum haemoglobin rose only 16 mg. and there was no haemoglobinuria (Table I).

For study of the effect of trauma to the hands the patient performed karate-type exercises. These entailed beating the ulnar borders of the hands fast and hard on a wooden block for 20 minutes. Though the serum haemoglobin rose $40 \mathrm{mg}$., the haemoglobin-binding power of the haptoglobin was not exceeded and haemoglobinuria did not occur. The results are detailed in Table I.

TABLE I

\begin{tabular}{|c|c|c|c|c|c|c|c|c|c|c|c|}
\hline & & & & & & & Before test & End of run & 2 hours & 4 hours & 6 hours \\
\hline \multicolumn{12}{|l|}{ Blood: } \\
\hline \multirow{3}{*}{\multicolumn{3}{|c|}{ Plasma haemoglobin (mg. $100 \mathrm{ml}$.) }} & & $\int$ Run 1 & . & . & 24 & 98 & 60 & 25 & 7 \\
\hline & & & & $\left\{\begin{array}{l}\text { Run 2 } \\
\text { Karate }\end{array}\right.$ & $\begin{array}{l}\cdots \\
\ldots\end{array}$ & $\begin{array}{l}\ldots \\
. .\end{array}$ & $\begin{array}{r}20 \\
8\end{array}$ & $\begin{array}{l}36 \\
48\end{array}$ & $\begin{array}{l}20 \\
18\end{array}$ & $\begin{array}{r}29 \\
8\end{array}$ & 22 \\
\hline & & & & Run 1 & $\ldots$ & $\therefore$ & 38 & 46 & 11 & 15 & 16 \\
\hline \multirow{2}{*}{\multicolumn{3}{|c|}{ Plasma haptoglobin (mg./100 ml.) }} & . & Run 2 & .. & . & 32 & 21 & 5 & 2 & 2 \\
\hline \multirow{3}{*}{\multicolumn{2}{|c|}{$\begin{array}{l}\text { Serum complement (units) } \\
\text { Blood sugar (mg./100 ml.) } \\
\text { ne: }\end{array}$}} & $\ldots$ & & $\begin{array}{l}\text { Karate } \\
\text { Run } 1\end{array}$ & $\cdots$ & . & $\begin{array}{l}52 \\
60\end{array}$ & $\begin{array}{l}45 \\
64\end{array}$ & $\begin{array}{l}25 \\
60\end{array}$ & $\begin{array}{l}19 \\
60\end{array}$ & 64 \\
\hline & & . & $\cdots$ & $\cdots$ & . & . & 102 & 148 & 62 & 80 & 80 \\
\hline & & & & CRun 1 & .. & $\ldots$ & - & $+1+4$ & 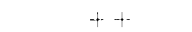 & $\therefore$ & + \\
\hline \multirow{2}{*}{ Albumin } & . & . & & $\{$ Run 2 & . & $\cdots$ & - & - & - & - & - \\
\hline & & & & $\begin{array}{l}\text { Karate } \\
\text { Run } 1\end{array}$ & $\therefore$ & $\begin{array}{ll}\ldots \\
\ldots\end{array}$ & 二 & $4 \overline{000}$ & $\overline{200}$ & - & 二 \\
\hline \multirow{2}{*}{\multicolumn{2}{|c|}{ Haemoglobin $(\mathrm{mg} .100 \mathrm{ml})}}$. & . & & Run 2 & $\because$ & $\cdots$ & - & - & 20 & - & 二 \\
\hline & & & & Karate & .. & . & - & - & & - & - \\
\hline Sediment & . & . & $\cdots$ & Run 1 & .. & & $\begin{array}{c}\text { Normal. } \\
\text { Haemosiderin-- } \\
\text { Normal }\end{array}$ & $\begin{array}{c}\text { Granular } \\
\text { casts }+ \\
\text { Haemosiderin } \\
\text { Granular } \\
\text { casts }+\end{array}$ & $\begin{array}{l}\text { Granular } \\
\text { casts }++ \\
\text { Haemosiderin }+ \\
\text { Normal }\end{array}$ & $\begin{array}{l}\text { Granular } \\
\text { casts }+. \\
\text { Haemosiderin } \pm \\
\text { Normal }\end{array}$ & $\begin{array}{l}\text { Granular } \\
\text { casts } \pm \text {. } \\
\text { Haemosiderin -- } \\
\text { Normal }\end{array}$ \\
\hline Cystine . & .. & . & . & $\begin{array}{l}\text { Karate } \\
\text { Run 1 }\end{array}$ & $\begin{array}{l}\cdots \\
\therefore\end{array}$ & $\begin{array}{l}\cdots \\
\cdots\end{array}$ & $\begin{array}{l}\text { Normal } \\
\text { Nil }\end{array}$ & $\begin{array}{c}\text { Normal } \\
\text { Nil }\end{array}$ & $\begin{array}{l}\text { Normal } \\
\text { Nil }\end{array}$ & $\begin{array}{c}\text { Normal } \\
\text { Nil }\end{array}$ & Nil \\
\hline
\end{tabular}

